\title{
PENGARUH GREEN PERCEIVED VALUE DAN GREEN BRAND IMAGE MELALUI GREEN SATISFACTION DAN GREEN TRUST TERHADAP GREEN BRAND EQUITY PADA PARIWISATA KREATIF DI JAWA BARAT
}

\author{
Asep Dedy \\ ARS University, Bandung, Indonesia \\ Email: dedy.ridan@gmail.com
}

\begin{abstract}
Abstrak
Industri pariwisata di Jawa Barat perlu mengembangkan model Green Marketing pada pariwisata kreatif karena pariwisata kreatif berpotensi besar dalam memberikan kontribusi ekonomi yang signifikan, menciptakan iklim bisnis yang positif, serta membangun citra dan identitas bangsa. Tujuan penelitian ini adalah untuk menganalisis pengaruh Green Brand Image dan Green Perceived Value melalui Green Brand Satisfaction dan Green Trust terhadap Green Brand Equity untuk diterapkan di bidang pariwisata kreatif di Jawa Barat. Metode penelitian yang digunakan adalah metode kuantitatif dengan survey sebagai instrumen utama. Survey dilakukan terhadap wisatawan di lima lokasi pariwisata kreatif di Jawa Barat, dengan sampel sebanyak 250 responden. Data dianalisis menggunakan Partial Least Square (PLS). Hasil penelitian memperlihatkan bahwa Green Perceived Value dan Green Brand Image berpengaruh signifikan terhadap Green Brand Equity melalui Green Brand Satisfaction dan Green Trust baik secara parsial dan simultan, dengan pengaruh terbesar yaitu Green Brand Image terhadap Green Satisfaction dan pengaruh terendah yaitu Green Satisfaction terhadap Green Brand Equity.
\end{abstract}

Kata kunci: Green Perceived Value, Green Brand Image, Green Satisfaction, Green Trust, Green Brand Equity, Pariwisata Kreatif.

\begin{abstract}
The tourism industry in West Java needs to develop a Green Marketing model in creative tourism because creative tourism has great potential in making a significant economic contribution, creating a positive business climate, and building the nation's image and identity. The purpose of this study is to analyze the influence of Green Brand Image and Green Perceived Value through Green Brand Satisfaction and Green Trust on Green Brand Equity to be applied in the creative tourism in West Java. The research method used is a quantitative method with a survey as the main instrument. The survey was conducted on tourists in five creative tourism locations in West Java, with a sample of 250 respondents. Data were analyzed using Partial Least Square (PLS). The results showed that Green Perceived Value and Green Brand Image had a significant effect on Green Brand Equity through Green Brand Satisfaction and Green Trust partially and simultaneously, with the biggest effect, namely Green Brand Image on Green Satisfaction and the lowest effect, namely Green Satisfaction on Green Brand Equity.
\end{abstract}

Keywords: Green Perceived Value, Green Brand Image, Green Satisfaction, Green Trust, Green Brand Equity, Creative Tourism. 


\section{A. PENDAHULUAN}

Salah satu isu yang paling penting yang mempengaruhi industri pariwisata dalam beberapa tahun terakhir adalah pariwisata yang berkelanjutan. Pariwisata semakin banyak digunakan sebagai alat pembangunan ekonomi suatu negara dalam membantu menciptakan lapangan kerja serta meningkatkan infrastruktur lokal. Masalah muncul ketika pembangunan dilakukan dengan tidak mempertimbangkan lingkungan terutama dalam kaitannya dengan perlindungan lingkungan. Selama tiga dekade terakhir, isu-isu yang berkaitan dengan lingkungan dan pembangunan berkelanjutan telah berevolusi dari menjadi topik hangat dan menjadi fokus pertimbangan dan penelitian. Beberapa faktor yang telah mendorong perubahan ini adalah besarnya liputan media, kesadaran yang lebih tinggi terhadap lingkungan yang dipengaruhi oleh laporan tentang berbagai bencana ekologi, aktivitas dari kelompok-kelompok stakeholder yang fokus pada isu-isu lingkungan, dan peraturan perundang-undangan yang semakin ketat di tingkat nasional dan internasional (Meler \& Ham, 2012).

Indonesia merupakan suatu negara yang memiliki berbagai potensi yang tersebar di seluruh penjuru. Pemerintah Indonesia, melalui Instruksi Presiden No. 6 Tahun 2009 tentang Pengembangan Ekonomi Kreatif, memerintahkan seluruh kementerian, termasuk kepala lembaga pemerintah non departemen, gubernur, bupati/walikota, dan pihak-pihak terkait lainnya, untuk mendukung kebijakan Pengembangan Ekonomi Kreatif tahun 2009-2015, yaitu pengembangan kegiatan ekonomi berdasarkan pada kreativitas, keterampilan, dan bakat individu untuk menciptakan daya kreasi dan daya cipta individu yang bernilai ekonomis dan berpengaruh terhadap kesejahteraan seluruh masyarakat Indonesia. Salah satu aspek utama pendukung kegiatan ekonomi kreatif ini adalah pariwisata kreatif (creative tourism) di beberapa tujuan wisata di seluruh Indonesia. Deklarasi program pengembangan ekonomi kreatif Indonesia hingga tahun 2025 adalah bentuk optimisme dan apresiasi terhadap masyarakat Indonesia dalam mendukung visi untuk menjadi negara maju. Di dalamnya terdapat ide, cita-cita, imajinasi dan mimpi untuk menjadi sebuah komunitas dengan kualitas hidup yang tinggi, makmur dan kreatif (Gunaryo, 2008).

Menurut Howkins (2013), ekonomi kreatif terdiri dari periklanan, arsitektur, seni, kerajinan, desain, fashion, film, musik, seni pertunjukan, penerbitan, penelitian dan pengembangan, perangkat lunak, mainan dan permainan, televisi, radio dan permainan video. Industri kreatif dipandang semakin penting dalam mendukung kesejahteraan dalam perekonomian, sehingga kreativitas manusia merupakan sumber daya ekonomi utama dan bahwa industri abad kedua puluh satu akan tergantung pada produksi pengetahuan melalui kreativitas dan inovasi. Saat ini penerapan ekonomi hijau (green economy) juga telah menjadi perhatian ekonomi kreatif dan industri pariwisata, yang tidak hanya memberikan keuntungan bagi wisatawan tapi juga memberikan keuntungan bagi usaha menjaga kelestarian lingkungan hidup.

Jawa Barat memiliki potensi tinggi dalam pengembangan pariwisata kreatif dan warisan budaya sehingga dapat menambah keanekaragaman wisata kota yang telah ada. Banyaknya event, monumen, bangunan, dan situs bersejarah di Jawa Barat dapat menjadi daya tarik tersendiri bagi wisatawan, baik domestik maupun mancanegara. Dalam hal ini, pariwisata sebagai salah satu sektor yang termasuk dalam kegiatan unggulan yang juga mencakup ekonomi, sosial, serta konservasi dan pelestarian lingkungan dan budaya. 
Berbagai potensi yang dimiliki Jawa Barat dalam pengembangan ekonomi dan pariwisata kreatif ini menarik perhatian pemerintah daerah dan pemerintah pusat dalam rangka meningkatkan pendapatan dan keunggulan daerah. Namun, arah kebijakan dalam mempromosikan industri ini belum jelas.

Ekonomi kreatif digunakan untuk melestarikan nilai-nilai budaya, yang juga bisa bernilai ekonomis. Industri budaya tradisional yang ada dapat "berubah" namanya menjadi industri kreatif. Aktivitas wisata seperti ini secara tidak langsung juga menghidupkan kembali tradisi dan kesenian tradisional yang mulai dilupakan oleh generasi muda. Upaya pelibatan masyarakat secara ekonomi dalam kegiatan pengembangan kepariwisataan dan upaya konservasi/perlindungan lingkungan alam, pengembangan produk wisata yang berbasis nilai dan budaya lokal ini merupakan strategi pengembangan kepariwisataan yang berbasis nilainilai keberlanjutan dan kepedulian terhadap lingkungan.

Pemasaran pariwisata bertanggung jawab menambahkan prinsip-prinsip keberlanjutan sebagai variabel dalam standar pengambilan keputusan pemasaran. khususnya terkait dengan aspek-aspek dalam pemasaran pariwisata. Pemasaran yang bertanggung jawab secara umum juga dikenal dengan istilah green marketing (Ottman, 1993) atau environmental marketing (Coddington, 1993).

Pemasaran yang bertanggung jawab merupakan serangkaian proses pemasaran yang meliputi pemilihan target pasar, penciptaan brand destinasi yang berkelanjutan, dan memastikan delivery produk wisata yang menjamin hak-hak wisatawan, memberi manfaat ekonomi pada penduduk, dan melindungi sumber daya budaya dan lingkungan. Pemasaran pariwisata yang bertanggung jawab mempunyai peran yang signifikan dalam mengangkat keunggulan branding daya tarik wisata Indonesia menjadi keunggulan saing kepariwisataan Indonesia secara berkelanjutan (Dewi, 2011). Berbagai riset empiris menunjukkan bahwa branding dapat meningkatkan citra (image) destinasi dan membantu meningkatkan angka kunjungan wisatawan asing ke destinasi tersebut (Telisman-Kosuta, 1989).

Kotler \& Keller (2012) menyatakan bahwa pemasar membangun ekuitas merek dengan menciptakan struktur pengetahuan merek pada konsumen yang tepat. karena itu pemasar harus menargetkan kelompok konsumen yang peduli terhadap lingkungan atau sekelompok konsumen hijau, dan harus membangun elemen merek seperti logo, simbol, karakter, slogan, juru bicara, paket dan tanda usia yang terkait dengan green brand untuk membangun merek yang kuat dalam jangka panjang.

Salah satu kriteria utama keberhasilan strategi branding adalah kemampuan untuk menghasilkan citra atau kepribadian yang unik sehingga mampu melakukan diferensiasi sebuah destinasi wisata dari destinasi-destinasi wisata lainnya. Titik tolak dari pembentukan image berarti seringkali adalah image sesuai yang telah dipersepsikan oleh wisatawan. Akan tetapi, proses branding juga memberikan ruang bagi pengembang strategi untuk menciptakan citra tertentu yang memang ingin diciptakan untuk suatu destinasi, dan setelah citra ini berhasil didefinisikan, akhirnya harus benar-benar bisa dirasakan oleh wisatawan (Dewi, 2011).

Penerapan konsep green marketing digunakan untuk mengembangkan strategi diferensiasi untuk memperoleh keunggulan kompetitif (Chen \& Chang, 2013). Chen (2008) menyatakan bahwa terdapat lima alasan bagi perusahaan untuk mengadopsi pemasaran hijau, yaitu: meningkatkan citra perusahaan, sesuai dengan trend lingkungan, memperoleh 
keunggulan kompetitif, mencari pasar baru atau peluang baru, dan meningkatkan nilai produk.

Elemen pertama terkait dengan Green Brand Image yang seringkali merupakan citra hijau yang dibentuk dan dipunyai oleh wisatawan sendiri atas suatu tempat. Titik tolak dari pembentukan image berarti seringkali adalah image sesuai yang telah dipersepsikan oleh wisatawan. Akan tetapi, proses branding juga memberikan ruang bagi pengembang strategi untuk menciptakan citra tertentu yang memang ingin diciptakan untuk suatu destinasi, dan setelah citra ini berhasil didefinisikan, akhirnya harus benar-benar bisa dirasakan oleh wisatawan.

Konsep green marketing berkaitan erat dengan kepuasan pelanggan dianggap sebagai faktor penting dalam menjalin hubungan jangka panjang dengan konsumen (Chen, 2010). Kepuasan terhadap produk hijau didefinisikan sebagai pelanggan yang merasa dengan mengonsumsi produk ramah lingkungan untuk memenuhi kebutuhan, keinginan dan tujuannya mengenai masalah lingkungan dan pemenuhan ini adalah hal yang menyenangkan. Kepercayaan wisatawan terhadap implementasi konsep wisata yang peduli terhadap lingkungan dipersepsikan oleh wisatawan sebagai Green Trust, Green Trust, bahwa Kepercayaan merupakan salah satu faktor utama yang mempengaruhi pembelian. Kepercayaan mengacu pada keyakinan individu bahwa konsumen akan berperilaku berdasarkan harapannya. Kepercayaan konsumen adalah dasar pertimbangan dan harapan konsumen dengan tingkat kepercayaan diri dalam harapan kepada pihak lain yang akan mengarah pada perilaku konsumen jangka panjang (Lee et al., 2011 ).

Terkait dengan green marketing, maka green brand image, green satisfaction, dan green trust wisatawan menjadi isu yang penting. Pariwisata kreatif di Jawa Barat pada dasarnya telah berupaya mengimplementasikan berbagai program peningkatan green brand equity wisatawan melalui penguatan green brand image, green brand satisfaction, dan green trust wisatawan. Terkait dengan hal tersebut, implementasi green brand image, green satisfaction, dan green trust wisatawan, dan green brand equity pada industri pariwisata kreatif di Jawa Barat perlu diperhatikan dengan melakukan penelitian secara empirik.

Berdasarkan uraian tersebut, tujuan penelitian ini adalah menganalisis pengaruh green perceived value dan green brand image melalui green satisfaction dan green trust terhadap green brand equity pada pariwisata kreatif di Jawa Barat.

\section{B. TINJAUAN PUSTAKA}

\section{Green Brand Image}

Menurut Kotler \& Keller (2012), brand adalah nama, istilah, tanda, simbol, desain atau kombinasi keseluruhannya, yang ditujukan untuk mengidentifikasikan barang atau jasa penjual atau kelompok penjual dan untuk membedakannya dari barang atau jasa pesaing. Green Brand Image adalah seperangkat persepsi dan asosiasi dalam benak konsumen dengan komitmen lingkungan dan masalah lingkungan (Padgett \& Allen, 1997). Green Brand Image didefinisikan sebagai suatu rangkaian persepsi dan asosiasi dalam pikiran konsumen pada suatu merek tertentu yang memiliki komitmen dan peduli terhadap pelestarian lingkungan (Cretu \& Brodie, 2007). Chen (2009) berpendapat bahwa Green Brand Image seperangkat persepsi dari merek di benak konsumen yang terkait dengan komitmen lingkungan dan kepedulian lingkungan. Dapat disimpulkan bahwa Green Brand Image merupakan persepsi 
dan asosiasi konsumen mengenai suatu merek yang ada pada suatu produk atau layanan yang memiliki hubungan dengan komitmen dan kepedulian terhadap lingkungan.

Menurut Chen (2010) terdapat lima indikator Green Brand Image, yaitu:

a. Mempunyai kredibilitas tinggi dalam menjaga komitmennya terhadap lingkungan.

b. Merek memiliki reputasi yang baik terhadap lingkungan.

c. Merek memiliki kesuksesan dalam menjaga lingkungan.

d. Merek memiliki kepedulian tinggi terhadap lingkungan.

e. Janji yang dimiliki merek dapat dipercaya dalam menjaga kelestarian lingkungan.

\section{Green Satisfaction}

Oliver (1999) menjelaskan bahwa kepuasan pelanggan adalah perasaan senang atau kecewa yang didapatkan seseorang dari membandingkan antara kinerja (atau hasil) produk yang dipersepsikan dengan ekspetasinya. Menurut Kotler \& Keller (2012) kepuasan adalah perasaan senang atau kecewa seseorang yang akan muncul setelah membandingkan antara kinerja (hasil). Green Satisfaction menurut Chen (2010) adalah tingkat pemenuhan konsumsi yang menyenangkan terkait untuk memuaskan keinginan pelanggan pada lingkungan, harapan berkelanjutan dan kebutuhan produk hijau. Di sini, green satisfaction mengacu pada kesediaan konsumen untuk mengharapkan efektivitas lingkungan dari produk atau layanan (atau merek) karena produk atau layanan yang handal, ramah lingkungan dan memiliki kapabilitas terhadap green produk. Dapat disimpulkan bahwa green satisfaction adalah perasaan puas yang dirasakan konsumen ketika keinginan dan kebutuhan konsumen terhadap green produk yang ramah lingkungan terpenuhi ataupun melebihi apa yang diharapkan.

Menurut Chen (2010) terdapat empat indikator untuk mengukur Green Satisfaction adalah sebagai berikut:

a. Kebahagiaan dalam memutuskan memilih merek hijau. Artinya, konsumen senang dengan keputusannya dalam memilih merek yang memiliki komitmen terhadap lingkungan.

b. Kepercayaan membeli merek hijau yang tepat. Artinya, konsumen percaya bahwa membeli merek yang memiliki kinerja terhadap lingkungan adalah hal yang tepat.

c. Kesenangan membeli merek hijau. Artinya, secara keseluruhan konsumen senang untuk membeli merek yang ramah lingkungan.

d. Kepuasan membeli merek hijau. Artinya, secara keseluruhan konsumen puas dengan merek yang memiliki kepedulian terhadap lingkungan.

\section{Green Trust}

Kepercayaan (trust) mengacu pada keyakinan individu bahwa konsumen akan berperilaku berdasarkan harapannya. Kepercayaan konsumen adalah dasar pertimbangan dan harapan konsumen dengan tingkat kepercayaan diri dalam harapan kepada pihak lain yang akan mengarah pada perilaku konsumen jangka panjang (Lee et al, 2015). Definisi produk ramah lingkungan pada dasarnya bergantung pada keyakinan sebagai konsumen tidak bisa pasti jika hanya menilai produk ini tentu ramah lingkungan bahkan setelah mereka mengonsumsi (Al-Otoum \& Nimri, 2015). Konsumen tidak hanya mengandalkan produk hijau tanpa informasi sebelumnya tentang dampak lingkungan (Vaishnavi, 2014). Dapat disimpulkan bahwa Green Brand Trust merupakan kehendak serta keyakinan konsumen dan 
pada suatu produk atau layanan dari sebuah merek, bahwa pada sebuah produk, jasa, atau merek berkomitmen mengenai janjinya terhadap kinerja lingkungan, berdasarkan kredibilitas, perbuatan, dan kecakapan kinerja lingkungan.

Lima dimensi green trust menurut Chen (2010) adalah:

a. Komitmen merek terhadap lingkungan dapat diandalkan.

b. Kinerja merek terhadap lingkungan umumnya dapat dipertanggungjawabkan

c. Argumen kelingkunganan yang dimiliki merek dapat dipercaya.

d. Kepedulian kelingkunganan merek memenuhi harapan.

e. Merek memegang janji dan komitmen untuk memberikan perlindungan terhadap lingkungan

\section{Green Perceived Value}

Perceived value mengacu pada hubungan antara harga yang wajar dan nilai yang tinggi yang diharapkan pelanggan atau selisih antara nilai yang didapatkan pelanggan dengan menggunakan produk atau jasa, dibandingkan dengan semua biaya yang terkait untuk memiliki produk tersebut (Kotler \& Keller, 2012 ). Green Perceived Value menurut Ng et al., (2014) adalah penilaian pelanggan pada atribut supremasi keseluruhan atau kinerja dari merek/produk yang berkaitan dengan sasaran yang dimaksudkan. Pada dasarnya, Green Brand Perceived Value adalah persepsi dan penilaian pelanggan terhadap net benefit suatu produk atau layanan yang berkaitan dengan lingkungan, antara apa yang diterima dan apa yang diberikan berdasarkan keinginan konsumen terhadap kepedulian lingkungan, harapan berkelanjutan dan green need.

Dimensi Green Perceived Value menurut Ng et al., (2014) adalah sebagai berikut:

a. Fungsi lingkungan merek memberikan nilai yang sangat baik.

b. Kinerja lingkungan merek memenuhi harapan

c. Membeli merek ini karena ramah lingkungan.

d. Membeli merek karena memiliki lebih manfaat lingkungan dibandingkan produk lainnya

\section{Green Brand Equity}

Brand equity adalah seperangkat asosiasi dan perilaku terhadap pelanggan, saluran distribusi dan pemilik perusahaan, dengan memfasilitasi brand untuk mendapatkan keuntungan dari produk non-branded, yang memiliki nilai tambah bagi produk dan jasa dengan merefleksikan perasaan konsumen, yang merupakan aset yang tidak berwujud, serta memiliki nilai psikologis dan keuangan terhadap organisasi (Kotler \& Keller, 2012). Brand Equity adalah nilai tambah untuk produk dan layanan dengan merefleksikan cara-cara perasaan atau bertindak konsumen. Ia berfokus pada brand dan harga, pangsa pasar dan kemampuan untuk membuat keuntungan. Ekuitas brand merupakan aset yang tidak berwujud, yang memiliki dua nilai yaitu nilai psikologis dan nilai keuangan terhadap organisasi. Berdasarkan model David Aaker, Brand Equity dapat menentukan pemasaran dan nilai keuangan dari kekuatan brand di pasar. Brand Equity memiliki lima elemen sebagai driver nilai, yaitu; brand asset sebagai hak cipta, brand awareness, brand loyalty, perceived quality dan brand associations (Severi dan Ling, 2013). 
Dalam penelitian ini, terdapat dimensi dari green brand equity mengacu pada pendapat Chen (2010):

a. komitmen brand terhadap lingkungan

b. fitur brand terkait lingkungan

c. preferensi brand lingkungan

d. perbandingan dengan brand lain

\section{Kerangka Berpikir dan Hipotesis Penelitian}

Pada penelitian ini green brand perceived value $(\mathrm{x} 4)$ dan green brand image $(\mathrm{x} 1)$ adalah sebagai variabel eksogen, green satisfaction (x2) dan green trust (x3) sebagai variabel intervening, dan green brand equity (y) sebagai variabel endogen. Berdasarkan berbagai penelitian sebelumnya, model yang dikembangkan pada penelitian ini adalah sebagai berikut.

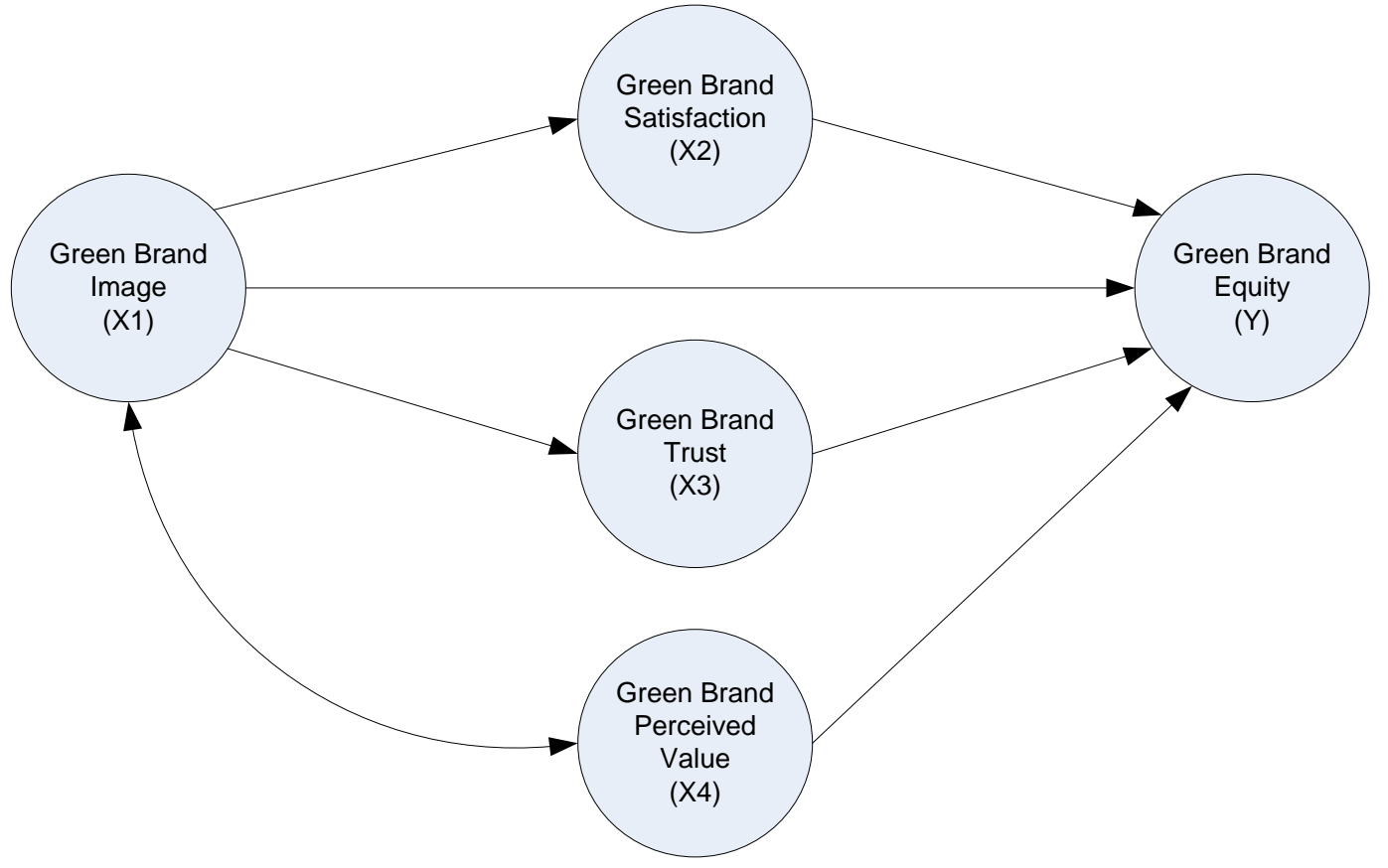

Gambar 1 Model Green Brand Equity

Dengan demikian, maka hipotesis yang diajukan oleh peneliti dalam penelitian ini adalah sebagai berikut:

a. Green brand image berpengaruh positif terhadap green brand satisfaction

b. Green brand image berpengaruh positif terhadap green brand trust

c. Green brand image berpengaruh positif terhadap green brand equity, secara langsung maupun tidak langsung

d. Green brand satisfaction berpengaruh positif terhadap green brand equity

e. Green brand trust berpengaruh positif terhadap green brand equity

f. Green brand perceived value berpengaruh positif terhadap green brand equity

\section{METODE PENELITIAN}

Penelitian ini dilakukan di lima objek pariwisata kreatif di Jawa Barat, yaitu Saung Angklung Udjo, Kampung Dago Pojok, dan Kampung Kreatif di Kota Bandung, Taman Bumi Ciletuh Kabupaten Sukabumi, dan Pantai Pangandaran. Metode yang digunakan dalam 
penelitian ini adalah explanatory survey (Kerlinger \& Lee, 2000). Penelitian ini bersifat deskriptif dan verifikatif (Aaker et al., 2008:755). Populasi dalam penelitian ini adalah seluruh wisatawan (nusantara dan mancanegara) yang datang ke objek-objek pariwisata kreatif tersebut pada bulan Juli 2019 yang ditarik secara purposive sampling (Hair et al., 2013). Dalam penelitian ini, 250 responden dijadikan sampel untuk dianalisis.

Variabel-variabel dalam penelitian ini terdiri dari lima variabel yaitu Green Brand Image (X1), Green Brand Satisfaction (X2), Green Brand Trust (X3), Green Brand perceive value (X4) dan Green Brand Equity (Y). Pengumpulan data penelitian ini menggunakan kuesioner. Sebelum instrumen disebar ke lapangan, terlebih dahulu dilakukan uji validitas dan reliabilitas instrumen. Pada penelitian ini, digunakan dua jenis analisis (1) analisis deskriptif untuk mengukur kinerja masing-masing variabel dan (2) analisis verifikatif berupa pengujian hipotesis dengan menggunakan Partial Least Square (PLS).

\section{HASIL DAN PEMBAHASAN}

\section{Analisis Deskriptif}

Analisis deskriptif setiap variabel dalam penelitian ini ditujukan untuk memperoleh gambaran analisis setiap variabel yang diteliti yaitu variabel Green Brand Image (GI), Green Satisfaction (GS), Green Trust (GT), dan Green Perceived Value (GPV), dan Green Brand Equity $(G B E)$. Hal ini bermanfaat sebagai pendukung dalam pengujian hipotesis. Hasil analisis deskriptif terhadap variabel-variabel yang diteliti dapat dilihat pada tabel 1:

Tabel 1. Ringkasan Capaian Rata-rata Indikator Setiap Variabel

\begin{tabular}{ccc}
\hline Indikator & Rata-rata & Kecenderungan \\
\hline GI-1 & 3.30 & Tinggi \\
GI-2 & 3.10 & Tinggi \\
GI-3 & 3.12 & Tinggi \\
GI-4 & 3.08 & Tinggi \\
GI-5 & 3.21 & Tinggi \\
\hline GI & $\mathbf{3 . 1 6}$ & Tinggi \\
\hline GS-1 & 3.09 & Tinggi \\
GS-2 & 3.24 & Tinggi \\
GS-3 & 3.13 & Tinggi \\
GS-4 & 3.38 & Tinggi \\
\hline GS & $\mathbf{3 . 2 1}$ & Tinggi \\
\hline GT-1 & 3.12 & Tinggi \\
GT-2 & 3.16 & Tinggi \\
GT-3 & 2.84 & Rendah \\
GT-4 & 2.88 & Rendah \\
GT-5 & 3.04 & Tinggi \\
\hline GT & $\mathbf{3 . 0 0}$ & Tinggi \\
\hline GPV-1 & 3.34 & Tinggi \\
GPV-2 & 3.28 & Tinggi \\
GPV-3 & 3.29 & Tinggi \\
GPV-4 & 3.28 & Tinggi \\
\hline GPV & $\mathbf{3 . 3 0}$ & Tinggi \\
\hline
\end{tabular}


ARTIKEL

\begin{tabular}{ccc} 
GBE-1 & 3.48 & Tinggi \\
GBE-2 & 3.49 & Tinggi \\
GBE-3 & 3.40 & Tinggi \\
GBE-4 & 3.42 & Tinggi \\
\hline GBE & $\mathbf{3 . 4 5}$ & Tinggi \\
\hline
\end{tabular}

Sumber: Hasil Pengolahan Data

Tabel 1 di atas menunjukkan bahwa hampir semua indikator pada setiap variabel cenderung sudah tinggi (dengan rata-rata di atas median $=3$ ), kecuali untuk indikator GT-3 dan GT-4 cenderung rendah. Dalam hal ini, pengunjung destinasi pariwisata kreatif di Jawa Barat belum sepenuhnya memiliki keyakinan terhadap kredibilitas pengelola terkait lingkungan hijau dan belum sepenuhnya memiliki keyakinan terhadap upaya pengelola terkait lingkungan hijau.

\section{Analisis Verifikatif (Pengujian Model)}

Analisis verifikatif untuk pengujian hipotesis penelitian ini menggunakan Structural Equation Modeling Partial Least Square (SEM-PLS). PLS merupakan suatu metode regresi berbasis variance untuk membuat model yang berorientasi pada prediksi sebagai alternatif dari SEM yang berbasis covariance. PLS ini termasuk pada statistik parametrik yang memiliki asumsi data penelitian bebas distribusi (distribution-free), yang artinya data penelitian tidak mengacu pada salah satu distribusi normal tertentu (misalnya distribusi normal). Dalam hal ini, PLS merupakan metode alternatif dari Structural Equation Modeling (SEM) yang dapat digunakan untuk mengatasi permasalahan hubungan antara variabel yang kompleks, dengan ukuran data relatif kecil (30 sampai 100).

PLS digunakan untuk mengetahui kompleksitas hubungan suatu konstruk (variabel laten) dengan konstruk lain, serta hubungan suatu konstruk dengan indikator-indikatornya (variabel manifes atau measured atau observed). PLS dan SEM ini dapat menjelaskan kompleksitas hubungan antar variabel yang pada praktiknya variabel-variabel tersebut pada bidang tertentu tidak dapat diukur secara langsung (bersifat laten atau tersembunyi) sehingga membutuhkan indikator-indikator (manifes) untuk mengukurnya.

PLS didefinisikan oleh dua persamaan, yaitu inner model dan outer model. Inner model menentukan spesifikasi hubungan antara konstruk dan konstruk lain (antar variabel laten), sedangkan outer model menentukan spesifikasi hubungan antara konstruk dengan indikator-indikatornya (variabel manifes). Konstruk itu sendiri dibagi dua, yaitu konstruk eksogen dan konstruk endogen. Konstruk eksogen merupakan konstruk penyebab, yaitu konstruk yang tidak dipengaruhi oleh konstruk lainnya. Konstruk eksogen ini memberikan pengaruh terhadap konstruk lainnya (konstruk endogen). PLS dapat bekerja untuk model hubungan konstruk dan indikator-indikatornya yang bersifat reflektif dan formatif, sedangkan SEM hanya bekerja pada model hubungan yang bersifat reflektif saja (Ghazali, 2006). Model pada penelitian ini adalah model hubungan reflektif.

Berbeda dengan SEM berbasis covariance, secara khusus evaluasi model SEM-PLS dibagi menjadi dua, yaitu:

a. Evaluasi outer model (model pengukuran), yang meliputi nilai outer loading (valid bila outer loading > 0,5 dan idealnya outer loading $>0,7)$, average variance extracted $(\mathrm{AVE})$ valid bila $>0,5$, dan composite reliability $(\mathrm{CR})$ valid bila $>0,8$. 
ARTIKEL

b. Evaluasi inner model (model struktural), meliputi nilai latent variable correlations (valid bila $\mathrm{r}>0,5$ ), path coefficients (jika $r$ valid, maka koefisien jalur signifikan), dan $R$-square $\left(\mathrm{R}^{2}\right.$ berarti keragaman atau variansi konstruk endogen yang mampu dijelaskan oleh konstruk-konstruk eksogen secara bersamaan).

Model pengukuran untuk setiap indikator dan variabel yang diteliti dapat diringkas pada Tabel 4 sebagai berikut:

Tabel 2 Ringkasan Model Pengukuran

\begin{tabular}{|c|c|c|c|c|c|c|}
\hline Construct & Indicator & Loading & $\begin{array}{l}\text { Composite } \\
\text { Reliability }\end{array}$ & AVE & $\begin{array}{c}\text { Cronbach } \\
\text { Alpha }\end{array}$ & Keterangan \\
\hline \multirow[t]{5}{*}{ GBI } & GBI1 & 0.889 & \multirow{5}{*}{0.949} & \multirow{5}{*}{0.787} & \multirow{5}{*}{0.932} & \multirow{5}{*}{ Fit model } \\
\hline & GBI2 & 0.892 & & & & \\
\hline & GBI3 & 0.890 & & & & \\
\hline & GBI4 & 0.885 & & & & \\
\hline & GBI5 & 0.878 & & & & \\
\hline \multirow[t]{4}{*}{ GS } & GS1 & 0.893 & \multirow{4}{*}{0.940} & \multirow{4}{*}{0.797} & \multirow{4}{*}{0.914} & \multirow{4}{*}{ Fit model } \\
\hline & GS2 & 0.913 & & & & \\
\hline & GS3 & 0.878 & & & & \\
\hline & GS4 & 0.887 & & & & \\
\hline \multirow[t]{5}{*}{ GT } & GT1 & 0.843 & \multirow{5}{*}{0.935} & \multirow{5}{*}{0.743} & \multirow{5}{*}{0.913} & \multirow{5}{*}{ Fit model } \\
\hline & GT2 & 0.817 & & & & \\
\hline & GT3 & 0.896 & & & & \\
\hline & GT4 & 0.871 & & & & \\
\hline & GT5 & 0.879 & & & & \\
\hline \multirow[t]{4}{*}{ GPV } & GPV1 & 0.907 & \multirow{4}{*}{0.945} & \multirow{4}{*}{0.810} & \multirow{4}{*}{0.921} & \multirow{4}{*}{ Fit model } \\
\hline & GPV2 & 0.913 & & & & \\
\hline & GPV3 & 0.900 & & & & \\
\hline & GPV4 & 0.880 & & & & \\
\hline \multirow[t]{4}{*}{ GBE } & GBE1 & 0.916 & \multirow{4}{*}{0.960} & \multirow{4}{*}{0.856} & \multirow{4}{*}{0.944} & \multirow{4}{*}{ Fit model } \\
\hline & GBE2 & 0.942 & & & & \\
\hline & GBE3 & 0.909 & & & & \\
\hline & GBE4 & 0.934 & & & & \\
\hline
\end{tabular}

Sumber: Pengolahan Data, 2019

Hasil perhitungan menunjukkan bahwa semua indikator pada setiap variabel laten memiliki path loading/coefficient > 0,5 bahkan > 0,7 yang menunjukkan bahwa setiap indikator tersebut secara signifikan (bermakna) mampu merefleksikan variabel laten. Hasil perhitungan tersebut juga menunjukkan nilai Composite Reliability $>0,7$; Average Variance Extracted $(\mathrm{AVE})>0,5$; dan Cronbach's Alpha $>0,7$. Semua nilai tersebut menunjukkan bahwa model pengukuran setiap variabel laten sudah memenuhi fit model.

Model struktural adalah model yang menghubungkan variabel laten eksogen dengan variabel laten endogen atau hubungan variabel endogen dengan variabel endogen lainnya. Hasil perhitungan menggambarkan model perhitungan sebagai berikut: 


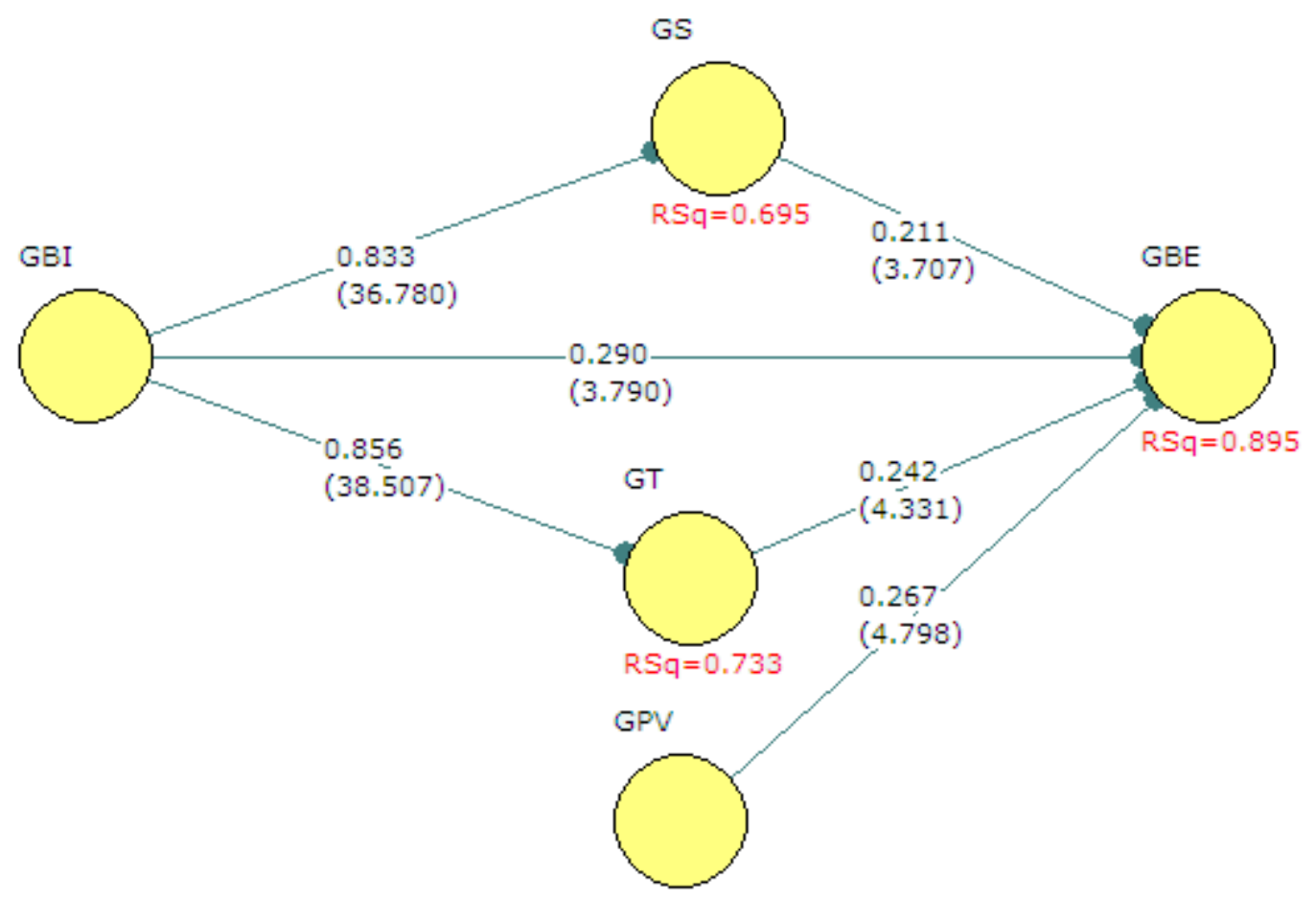

Gambar 2 Model Struktural Green Brand Equity

Berdasarkan model struktural tersebut, maka persamaan struktural dalam penelitian ini dapat diungkapkan sebagai berikut:

$\mathrm{GS}=0,833 \mathrm{GBI}$, dengan $\mathrm{RSq}=0,695$ dan $\mathrm{e}=0,305$

$\mathrm{GT}=0,856 \mathrm{GBI}$, dengan $\mathrm{RSq}=0,733$ dan $\mathrm{e}=0,267$

$\mathrm{GBE}=0,290 \mathrm{GBI}+0,267 \mathrm{GPV}+0,211 \mathrm{GS}+0,242 \mathrm{GT}$, dengan $\mathrm{RSq}=0,895$ dan $\mathrm{e}=0,105$

Secara keseluruhan, perhitungan jalur dan signifikansi untuk setiap model dapat dilihat pada tabel 3 sebagai berikut:

Tabel 3 Ringkasan Model Struktural

\begin{tabular}{|c|c|c|c|c|c|}
\hline \multicolumn{2}{|r|}{ Model } & \multirow{2}{*}{$\frac{\text { Jalur }}{0,833}$} & \multirow{2}{*}{$\begin{array}{c}\text { T-statistik } \\
36,780 \\
\text { (Signifikan) }\end{array}$} & \multirow{2}{*}{$\begin{array}{c}\text { Keputusan } \\
\text { Hipotesis } \\
\text { Diterima }\end{array}$} & \multirow{2}{*}{$\begin{array}{c}\text { Nilai } \mathbf{R}^{2} \text { dan e } \\
\text { RSq }=0,695 \\
\mathrm{e}=0,305\end{array}$} \\
\hline GS & GBI $\rightarrow$ GS & & & & \\
\hline GT & $\mathrm{GBI} \rightarrow \mathrm{GT}$ & 0,856 & $\begin{array}{c}38.507 \\
\text { (Signifikan) }\end{array}$ & $\begin{array}{l}\text { Hipotesis } \\
\text { Diterima }\end{array}$ & $\begin{array}{c}\mathrm{RSq}=0,733 \\
\mathrm{e}=0,267\end{array}$ \\
\hline \multirow[t]{4}{*}{ GBE } & $\mathrm{GBI} \rightarrow \mathrm{GBE}$ & 0,290 & $\begin{array}{c}3,790 \\
\text { (Signifikan) }\end{array}$ & $\begin{array}{l}\text { Hipotesis } \\
\text { Diterima }\end{array}$ & \multirow{4}{*}{$\begin{array}{c}\mathrm{RSq}=0,895 \\
\mathrm{e}=0,105\end{array}$} \\
\hline & $\mathrm{GPV} \rightarrow \mathrm{GBE}$ & 0,267 & $\begin{array}{c}3,707 \\
\text { (Signifikan) }\end{array}$ & $\begin{array}{l}\text { Hipotesis } \\
\text { Diterima }\end{array}$ & \\
\hline & $\mathrm{GS} \rightarrow \mathrm{GBE}$ & 0,211 & $\begin{array}{c}4,331 \\
\text { (Signifikan) }\end{array}$ & $\begin{array}{l}\text { Hipotesis } \\
\text { Diterima }\end{array}$ & \\
\hline & $\mathrm{GT} \rightarrow \mathrm{GBE}$ & 0,242 & $\begin{array}{c}4,798 \\
\text { (Signifikan) }\end{array}$ & $\begin{array}{l}\text { Hipotesis } \\
\text { Diterima }\end{array}$ & \\
\hline \multirow[t]{2}{*}{$\begin{array}{c}\text { (indirect } \\
\text { effect) }\end{array}$} & $G B I \rightarrow G S \rightarrow G B E$ & $0,176^{*}$ & $\begin{array}{c}4,422 \\
\text { (Signifikan) }\end{array}$ & \multicolumn{2}{|c|}{$\begin{array}{l}\text { GS dapat menjadi variabel } \\
\text { intervening }\end{array}$} \\
\hline & $G B I \rightarrow G T \rightarrow G B E$ & $0,202 *$ & $\begin{array}{c}5,162 \\
\text { (Signifikan) }\end{array}$ & \multicolumn{2}{|c|}{$\begin{array}{l}\text { GT dapat menjadi variabel } \\
\text { intervening }\end{array}$} \\
\hline
\end{tabular}

Keterangan: * = jalur tidak langsung; Tingkat Signifikansi $\alpha=0,05$. 
GBI berpengaruh secara signifikan terhadap GS pada industri pariwisata kreatif di Jawa Barat. Dalam hal ini, destinasi pariwisata kreatif di Jawa Barat tersebut telah berhasil menciptakan citra sebagai destinasi pariwisata kreatif di benak wisatawan dengan bentukbentuk pariwisata kreatifnya. Hal ini sejalan dengan pendapat Padgett \& Allen (1997) bahwa GBI adalah seperangkat persepsi dan asosiasi dalam benak konsumen dengan komitmen lingkungan dan masalah lingkungan. Hal ini merupakan nilai tersendiri bagi destinasi pariwisata kreatif di Jawa Barat untuk lebih meningkatkan kinerja pariwisata kreatifnya, dengan lebih memperhatikan aspek kepercayaan masyarakat terutama wisatawan yang peduli terhadap lingkungan, dimana pelaku usaha wisata dapat dipercaya dalam menjaga kelestarian lingkungan. Berdasarkan hasil penelitian ini wisatawan merasa belum puas dengan aspek tersebut.

GBI juga berpengaruh secara signifikan terhadap GT pada industri pariwisata kreatif di Jawa Barat. Reputasi yang baik terhadap lingkungan tentunya akan memberikan kepercayaan yang baik dari wisatawan yang peduli terhadap lingkungan, dimana kesadaran terhadap lingkungan pada wisatawan terutama wisatawan mancanegara sudah merupakan hal yang perlu diperhatikan oleh stakeholder pariwisata. Pentingnya peranan GBI terhadap kepercayaan wisatawan dapat dilihat dari pemahaman bahwa pariwisata adalah industri yang berbasis lingkungan serta pencitraan, karena citra mampu membawa calon wisatawan ke dunia simbol dan makna. Bahkan citra atau image dapat dikatakan memegang peranan lebih penting daripada sumberdaya pariwisata yang kasat mata, oleh karena itu, kepercayaan pelanggan dapat mempengaruhi pembelian keputusan mereka (Gefen \& Straub, 2004).

GBI secara langsung juga berpengaruh signifikan terhadap GBE pada industri pariwisata kreatif di Jawa Barat. Kesuksesan dalam menjaga lingkungan memberikan kontribusi terbesar terhadap GBE, pentingnya green brand equity karena ekuitas merek yang lebih tinggi dapat mengaktifkan konsumen untuk bersedia membayar lebih untuk tingkat yang sama kualitas karena daya tarik nama melekat pada produk (Chaudhuri \& Holbrook, 2001). Kesuksesan dalam menjaga lingkungan akan menyebabkan wisatawan bersedia membayar lebih mahal karena aktivitas kinerja pelestarian lingkungan yang diperhatikan oleh pariwisata kreatif.

GS berpengaruh secara signifikan terhadap GBE pada industri pariwisata kreatif di Jawa Barat. Wisatawan memutuskan untuk berkunjung ke destinasi tersebut karena kinerja yang baik dari pengelola destinasi tersebut terhadap lingkungan. Keputusan wisatawan untuk berkunjung tersebut merupakan akumulasi dari berbagai pertimbangan wisatawan, faktor lingkungan wisata yang nyaman dan berwawasan lingkungan merupakan nilai tersendiri dimana kepuasan pelanggan bisa menyebabkan niat beli konsumen dan perilaku pembelian ulang (Chang \& Tu, 2005). Akan tetapi belum sepenuhnya wisatawan merasa puas dengan kinerja destinasi pariwisata terhadap lingkungan, mungkin karena kebersihan yang tidak dikelola secara baik, serta kurang terawatnya lingkungan sekitar tempat pariwisata, sehingga wisatawan belum merasa puas, dimana kepuasan adalah tingkat konsumsi menyenangkan yang memenuhi kebutuhan pelanggan, keinginan, tujuan, atau sebagainya.

GT berpengaruh secara signifikan terhadap GBE pada industri pariwisata kreatif di Jawa Barat. Kepercayaan wisatawan terhadap kinerja pariwisata kreatif yang berwawasan lingkungan biasanya didasari oleh berbagai argumen yang dapat dipercaya. Harapan atau probabilitas tinggi konsumen sehingga merek akan mendapatkan evaluasi positif. mengingat 
Brand Trust sebagai harapan, didasarkan pada keyakinan konsumen bahwa merek tersebut konsisten, kompeten, jujur, dan bertanggung jawab (Doney \& Cannon, 1997), misalnya berdasarkan pengalaman, atau word of mouth yang diperoleh oleh wisatawan dari temantemannya, Relationship Marketing menyatakan bahwa kepercayaan adalah faktor utama yang didasarkan relasi (Delgado-Ballester \& Munuera-Alema'n, 2005). Pariwisata hijau akan dipersepsikan oleh wisatawan sebagai wisata yang memegang janji terhadap segala aspek yang berkaitan dengan lingkungan di tempat wisata tersebut. Kurangnnya apresiasi wisatawan dengan komitmen tempat wisata kreatif dapat mengurangi penilaian wisatawan terhadap Green Trust pariwisata kreatif.

GPV berpengaruh secara signifikan terhadap GBE pada industri pariwisata kreatif di Jawa Barat. Pada dasarnya wisatawan mempersepsi bahwa destinasi wisata tersebut memang memiliki brand equity tertentu yang berbasiskan lingkungan dan relatif sudah memenuhi harapan pengunjung. Sebagian pengunjung masih membanding-bandingkan satu destinasi wisata di Jawa Barat dengan destinasi wisata lainnya di luar Jawa Barat, misalnya dengan Bali. Menurut Ottman (1993), kesalahan mengabaikan proposisi nilai konvensional dalam green marketing adalah bahwa sebagian besar pengunjung memiliki kecenderungan menolak produk hijau karena kualitas produk tersebut dinilai lebih rendah dibandingkan dengan yang terdapat di tempat wisata lain.

GBI melalui GS dan GT berpengaruh signifikan terhadap GBE. Hal ini menunjukkan bahwa GS dan GT dapat menjadi variabel intervening dari GBI ke GBE. Dalam hal ini, pengaruh GBI akan lebih kuat bila melalui GS dan GT.

\section{E. KESIMPULAN}

Hasil penelitian ini membuktikan bahwa Green Perceived Value dan Green Brand Image berpengaruh signifikan terhadap Green Brand Equity melalui Green Brand Satisfaction dan Green Trust baik secara parsial dan simultan, dengan pengaruh terbesar yaitu Green Brand Image terhadap Green Satisfaction dan pengaruh terendah yaitu Green Satisfaction terhadap Green Brand Equity. Hasil ini berimplikasi bahwa bjek-objek pariwisata kreatif di Jawa Barat perlu meningkatkan pelayanan yang berkaitan dengan kepedulian terhadap lingkungan, dengan lebih memperhatikan kebersihan lingkungan baik di objek wisata tersebut, maupun pada lingkungan sekitar tempat wisata tersebut untuk meningkatkan green brand satisfaction wisatawan.

\section{DAFTAR PUSTAKA}

Meler, M., \&Ham, M. (2012). Green Marketing For Green Tourism. Faculty of Economics in Osijek, University of Osijek, Croatia. 130-139. 130.

Aaker, D. A., Kumar, V., \& Day, G. S. (2008). Marketing research. John Wiley \& Sons.

Hair, J. F., Black, W. C., Babin, B. J., \& Anderson, R. E. (2013). Multivariate data analysis: Pearson new international edition. Pearson Higher Ed.

Kerlinger, F. N., \& Lee, H. B. (2000). Foundations of behavioral research 4th ed. Holt, NY.

Severi, E., \& Ling, K. C. (2013). The mediating effects of brand association, brand loyalty, brand image and perceived quality on brand equity. Asian Social Science, 9(3), 125.

Ng, P. F., Butt, M. M., Khong, K. W., \& Ong, F. S. (2014). Antecedents of green brand equity: an integrated approach.Journal of Business Ethics, 121(2), 203-215. 
Al-Otoum, F. J., \& Nimri, R. S. (2015). Antecedents of Environmental Buying Behavior: Case of the Jordanian Market. International Journal of Business and Management, 10(9), 240.

Gunaryo. (2008). Pengembangan Ekonomi Kreatif Indonesia 2025 (Rencana Pengembangan Ekonomi Kreatif Indonesia 2009-2015). Kelompok Kerja Indonesia Design Power, Departemen Perdagangan RI.

Howkins, J. (2001). The Creative Economy: How People Make Money from Ideas. London: Penguin Global.

Ottman, J. A. (1993). Green Marketing: Challenges and Opportunities for the New Marketing Age, NTC Publishing Group, Lincoln wood

Coddington, Walter.(1993). Environmental Marketing: Positive Strategies for. Reaching the Freen Consumer. New York: McGraw-Hill Inc.

Dewi, Iker Janeta (2011). Implementasi dan Implikasi Kelembagaan pemasaran pariwisata yang bertanggungjawab. Kementerian Kebudayaan dan Pariwisata Republik Indonesia.

Telisman-Kosuta, N. (1989). Tourism Destination Image. En Witt, S.F.\& L. Moutinho (eds.). Tourism Marketing and Management Hand. Prentice Hall: Cambridge.

Kotler \& Keller (2012). Marketing Management. 14 ${ }^{\text {th }}$ edition, Global Edition. Pearson. Prentice Hall.

Chen, Y. S. (2010). The drivers of green brand equity: Green brand image, green satisfaction, and green trust. Journal of Business ethics, 93(2), 307-319.

Lee, H., Law, R., \& Murphy, J. (2011). Helpful reviewers in Trip Advisor, an online travel community. Journal of Travel \& Tourism Marketing. Vol.28(7), 675-688.

Padgett, D., \& Allen, D. (1997), "Communicating Experiences: A Narrative Approach to Creating Service Brand Image" Journal of Advertising, Vol. 26, No. 4 (Winter), 49-62.

Cretu, A. E., \& Brodie, R. J., 2015, The Influence of Brand Image and Company Reputation Where Manufacturers Market to Small Firms: A Customer Value Perspective. Industrial Marketing Management, 36 (2007) 230 - 240.

Oliver, R.L., (1999). Whence Consumer Loyalty, Journal of marketing., Volume 63 Special Issue, pp. 33-44.

Vaishnavi, G., \& B. S Abdurrahman. (2014). Environmental Behaviour of Consumers vis-àvis Customer Relationship, Trust and Loyalty: Some Research Reflections and Organisational Practices. Journal of Business Studies Quarterly. 6(2). 85-97.

Ghazali, I. (2006). Aplikasi Analisis Multivariate dengan Program SPSS, cetakan ke-4. Semarang: Badan Penerbit Universitas Diponegoro.

Gefen, D., \& Straub, D. W. (2004). Consumer trust in B2C e-Commerce and the importance of social presence: experiments in e-Products and e-Services. Omega, 32(6), 407-424.

Chaudhuri, A., \& Holbrook, M. B. (2001). The chain of effects from brand trust and brand affect to brand performance: the role of brand loyalty. Journal of marketing, 65(2), 81-93.

Chang, N. J., \& Fong, C. M. (2010). Green product quality, green corporate image, green customer satisfaction, and green customer loyalty. African Journal of Business Management,4(13), 2836-2844.

Chang, C. H., \& Tu, C. Y. (2005). Exploring store image, customer satisfaction and customer loyalty relationship: evidence from Taiwanese hypermarket industry. Journal of American Academy of Business, 7(2), 197-202.

Doney, P. M., \& Cannon, J. P., (1997) "An Examination of the Nature of Trust in BuyerSeller Relationships," Journal of Marketing, Volume 61, Number April 1997, 35-51.

Delgado-Ballester, E. \& Munuera-Alema'n, J.L. (2005), "Does brand trust matter to brand equity?”, Journal of Product and Brand Management, 14(2/3), 187-196. 